\title{
Gene Dosage Alterations Revealed by CDNA Microarray Analysis in Cervical Cancer: Identification of Candidate Amplified and Overexpressed Genes
}

\author{
Gopeshwar Narayan,' Veronique Bourdon, ${ }^{2}$ Seeta Chaganti, ${ }^{2}$ Hugo Arias-Pulido, ${ }^{3,4}$ \\ Subhadra V. Nandula, ' Pulivarthi H. Rao, ${ }^{5}$ Lutz Gissmann, ${ }^{6}$ Matthias Dürst, ${ }^{7}$ Achim Schneider, ${ }^{8}$ \\ Bhavana Pothuri, ${ }^{9}$ Mahesh Mansukhani, ${ }^{\prime}$ Katia Basso, ${ }^{10}$ R. S. K. Chaganti, ${ }^{2}$ and Vundavalli V. Murty ${ }^{1,10 *}$ \\ 'Department of Pathology, Columbia University Medical Center, NY 10032 \\ ${ }^{2}$ Cell Biology Program, Memorial Sloan-Kettering Cancer Center, NY I002I \\ ${ }^{3}$ Department of Tumor Molecular Biology, Instituto Nacional de Cancerología, Bogotá, Colombia \\ ${ }^{4}$ Department of Molecular Genetics and Microbiology, University of New Mexico, Albuquerque, NM \\ ${ }^{5}$ Baylor College of Medicine, Texas Children's Cancer Center, Houston, TX \\ ${ }^{6}$ Deutsches Krebsforschungszentrum, Im Neuenheiimer Feld 242, Heidelberg, Germany \\ 7 Department of Obstetrics and Gynecology, Friedrich Schiller University, Jena, Germany \\ ${ }^{8}$ Department of Gynecology, Charité Universitätsmedizin Berlin, Hindenburgdamm 30, Berlin, Germany \\ ${ }^{9}$ Department of Gynecologic Oncology, Columbia University Medical Center, NY 10032 \\ ${ }^{10}$ Institute for Cancer Genetics, Columbia University Medical Center, NY 10032
}

\begin{abstract}
Cervical cancer $(\mathrm{CC})$ cells exhibit complex karyotypic alterations, which is consistent with deregulation of numerous critical genes in its formation and progression. To characterize this karyotypic complexity at the molecular level, we used cDNA array comparative genomic hybridization $(\mathrm{aCGH})$ to analyze $29 \mathrm{CC}$ cases and identified a number of over represented and deleted genes. The aCGH analysis revealed at least 17 recurrent amplicons and six common regions of deletions. These regions contain several known tumor-associated genes, such as those involved in transcription, apoptosis, cytoskeletal remodeling, iontransport, drug metabolism, and immune response. Using the fluorescence in situ hybridization (FISH) approach we demonstrated the presence of high-level amplifications at the $8 q 24.3$, I Iq22.2, and 20q I 3 regions in CC cell lines. To identify amplification-associated genes that correspond to focal amplicons, we examined one or more genes in each of the 17 amplicons by Affymetrix UI33A expression arrays and semiquantitative reverse-transcription PCR (RT-PCR) in 3 I CC tumors. This analysis exhibited frequent and robust upregulated expression in CC relative to normal cervix for genes EPHB2 (IP36), CDCA8 (Ip34.3), AIM2 (Iq22-23), RFC4, MUC4, and HRASLS (3q27-29), SKP2 (5pI2-I3), CENTD3 (5q3I.3), PTK2, RECQL4 (8q24), MMPI and MMPI3 (I Iq22.2), AKTI (I4q32.3), ABCC3 (I7q2I-22), SMARCA4 (I9pI3.3) LIGI (I9qI3.3), UBE2C (20qI3.I), SMCILI (XpII), KIF4A (Xql2), TMSNB (Xq22), and CSAG2 (Xq28). Thus, the gene dosage and expression profiles generated here have enabled the identification of focal amplicons characteristic for the CC genome and facilitated the validation of relevant genes in these amplicons. These data, thus, form an important step toward the identification of biologically relevant genes in CC pathogenesis. This article contains Supplementary Material available at http://www.interscience.wiley.com/jpages/I0452257/suppmat. (C) 2007 Wiley-Liss, Inc.
\end{abstract}

\section{INTRODUCTION}

Cervical cancer (CC) displays a myriad cytogenetic abnormalities including chromosomal amplifications, gains, and deletions (Mitra et al., 1994a; Heselmeyer et al., 1996; Harris et al., 2003; Rao et al., 2004). Allelotype analysis has identified loss of heterozygosity (LOH) at 2q37, 3p, 4, 5p, 6p, 6q, 11q23, and 13q (Mitra et al., 1994a; Mullokandov et al., 1996; Rader et al., 1996; Pulido et al., 2000; Chatterjee et al., 2001; Narayan et al., 2003b). Frequent chromosomal amplification at $1 \mathrm{p} 31,2 \mathrm{q} 32$, 7q22, 8q22-24, 9p22, 10q21, 10q24, 11q13, 11q21, $12 \mathrm{q} 15, \quad 14 \mathrm{q} 12, \quad 17 \mathrm{p} 11.2, \quad 17 \mathrm{q} 22,18 \mathrm{p} 11.2$, and $19 q 13.1$, as well as gains at 1p32-36, 3q, 5p, 8q2324, 9q, 15q, 16p, 19q, 20q, and $\mathrm{X}$ have been reported by chromosomal CGH (cCGH) analysis (Narayan et al., 2003b; Rao et al., 2004). However, very few pathogenically recognizable genetic lesions have been identified thus far (Mitra et al., 1994b; Cappellen et al., 1999). Some of these genetic changes, such as $3 p$ and $6 p$ deletions, gain

Supported by: National Institutes of Health; Grant number: CA095647; Herbert Irving Comprehensive Cancer Center, Columbia University; Colciencias, Colombia.

*Correspondence to: Vundavalli V. Murty, Department of Pathology, Irving Cancer Research Center, Room 605, Columbia University Medical Center, 1130 St. Nicholas Avenue, New York 10032, USA. E-mail: vvm2@columbia.edu

Received 20 July 2006; Accepted 29 November 2006

DOI 10.1002/gcc.20418

Published online 22 January 2007 in

Wiley InterScience (www.interscience.wiley.com). 
of $3 q$, occur very early in the progression of $\mathrm{CC}$ (Heselmeyer et al., 1996; Kersemaekers et al., 1999; Chatterjee et al., 2001). However, the molecular nature of the global genetic changes recognized as complex cytogenetic alterations in CC remains poorly understood. Elucidation of these changes is critical for understanding the molecular basis of CC.

In an effort to identify the molecular alterations associated with invasive CG, we performed microarray $\mathrm{CGH}(\mathrm{aCGH})$ analysis to identify gene dosage changes in CC. This analysis identified 17 amplified and six deleted chromosomal regions characteristic of CC. FISH analysis demonstrated high-level amplifications at $8 \mathrm{q} 24.3,11 \mathrm{q} 22.2$, and 20q13, and increased copies of 3q. Affymetrix gene expression profile and RT-PCR analyses identified overexpression of a number of genes mapped within the focal amplicons in CG and enabled the identification of relevant transcriptional targets.

\section{MATERIALS AND METHODS}

\section{Tumor Specimens and Cell Lines}

A total of 54 CC cases ( 9 cell lines and 45 primary tumor specimens) and 16 normal cervical tissues obtained from hysterectomy specimens as controls were used in this study. Twenty-nine tumors (21 primary tumors-6 stage IB, 8 stage IIB, 7 stage IIIB; and 8 cell lines) were used in aCGH analysis and 25 additional tumors (24 primary tumors and one cell line) were used in expression studies. The cell lines (HT-3, ME-180, CaSki, MS751, C-4I, C-33A, SW756, HeLa, and $\mathrm{SiHa}$ ) were obtained from American Type Culture Collection (ATCG, Manassas, VA) and grown in tissue culture as per the supplier's specifications. The tumors were obtained from patients evaluated at the Instituto Nacional de Cancerologia (Santa Fe de Bogota, Colombia) (Pulido et al., 2000), the Department of the Obstetrics and Gynecology of Friedrich Schiller University (Jena, Germany), and Columbia University Medical Center, NY. All specimens were obtained after appropriate informed consent and approval of protocols by institutional review boards. The primary tumors were classified as FIGO stage IB (8 tumors), IIB (18 tumors) or IIIB/IV (19 tumors). Forty-two tumors were diagnosed as squamous-cell carcinoma (SCC) and three as adenocarcinoma. All tumor specimens were determined to contain at least $70 \%$ tumor cellularity by H\&E staining. High molecular weight DNA and total RNA from tumor and normal tissues, and cell lines were isolated by standard methods. DNA isolated from placenta was used as a reference in aCGH analysis.

\section{aCGH Hybridization and Image Analysis}

The EST arrays generated at the Albert Einstein College of Medicine microarray facility (www.aecom. yu.edu/cancer/new/cores/microarray/default.htm\#) contained 9,206 T3/T7 PCR-amplified cDNA inserts of human I.M.A.G.E. consortium clones printed on glass slides. The slides were hybridized as previously described (Bourdon et al., 2002). Briefly, the slides were first incubated for $1-5 \mathrm{hr}$ with $20 \mu \mathrm{l}$ of prehybridization mix. A total of $5 \mu \mathrm{g}$ of test and reference DNAs was digested with $D p n$ II for 1 hr, purified using a PCR clean-up kit (Promega, Madison, WI), and extracted in $50 \mu$ of water. Digested DNAs were concentrated by ultrafiltration (Microcon YM-30, Amicon; Millipore, Bedford, MA). Equal amounts of test and reference (placenta) DNAs $(1.8-2.2 \mu \mathrm{g})$ were labeled separately in $50 \mu \mathrm{l}$ reactions using Cy3-dUTP or Cy5dUTP (Amersham, Piscataway, NJ), respectively. The reaction mixtures were pooled, purified, and hybridized in the presence of a blocking reagent (Pollack et al., 1999). The slides were prepared after posthybridization washes as described (Bourdon et al., 2002).

The arrays were scanned using an Axon dual color laser scanner (GenePix 4000A; Axon, Union City, CA). At the time of the scanning, the laser power was adjusted to have $<5 \%$ features saturated; the digitized Cy3 and Cy5 signals were pseudocolored green and red, respectively (GenePix Pro 3.0; Axon). After gridding, each dot on the 24bit ratio image was visually inspected and unsatisfactory dots were manually flagged if necessary. A GenePix results (*.gpr) file of the raw data (F635 median-B635 median, F532 median-B532 median) was used for further analyses.

The signals obtained after laser excitation of the dyes were digitized, and the raw data (median feature pixel intensity with the median local background intensity subtracted at each wavelength) were then subjected to statistical analysis. To correct for systematic errors introduced by the intensity-dependent dye efficiencies, the hybridization signal data from each slide were normalized using a local regression of the log-ratio variable $Y=$ $\log _{2}(G / R)$ versus the log-product $X=\log _{10}(R \times G) /$ 2 ( $R$ and $G$ represent the intensities of the Cy3 and Cy5, respectively). It was important to construct an indicator to identify ESTs that exhibited significant signal deviation from normal in a given slide. To this end, we computed the intensity-dependent 
(local) variance $\sigma\left(X_{\mathrm{N}}\right)^{2}$ from a local regression of $Y_{\mathrm{N}}^{2}$ vs. $X_{\mathrm{N}}$ after normalization $\left(X_{\mathrm{N}}\right.$ and $Y_{\mathrm{N}}$ represent the normalized $X$ and $Y$ variables) and attributed significance to amplified/deleted ESTs according to the values of $Y_{\mathrm{N}} / \sigma\left(X_{\mathrm{N}}\right)(\mathrm{LR} / \mathrm{SD})$, independently for each slide (Bourdon et al., 2002). With the binomial distribution it is extremely unlikely to get more than two false positive calls out of 29 samples with a $P<0.001$. Therefore, a sequence was called amplified or deleted when the value $L R / S D$ was $\geq 3.1$ or $\leq-3.1$, respectively, in at least three tumor samples and none of the controls (three placenta versus placenta experiments). All EST clones on the array were mapped in silico using NCBI genome map viewer build 34.3 (www.ncbi.nlm.nih.gov/mapview/) and assigned to subchromosomal regions. The normalized data have been deposited in the Gene Expression Omnibus (GEO) database (Accession GSE1715) (www.ncbi.nlm.nih.gov/geo/).

\section{HPV Typing}

HPV types were determined as previously described (Narayan et al., 2003a).

\section{Semiquantitative RT-PCR Analysis}

Total RNA from normal cervix was obtained from three commercial sources (Ambion, Austin, TX; Stratagene, La Jolla, CA; BioChain, Hayward, CA). Total RNA was isolated from nine cell lines (eight used in aCGH analysis), 18 primary tumors (all SCG; nine of these also studied by aCGH), and five normal cervix were reverse transcribed using random primers and the Pro-STAR first strand RTPCR kit (Stratagene, La Jolla, CA). A semiquantitative analysis of gene expression was performed in duplicate or triplicate experiments using 26-28 cycles of multiplex RT-PCR with $\beta$-actin $(A C T B)$ as the control and gene specific primers spanning at least two exons (Supplementary Table 1; supplementary material for this article can be found at http://www.interscience.wiley.com/jpages/1045-2257/ suppmat).

The PCR products were run on $1.5 \%$ agarose gels, visualized by ethidium bromide staining and quantified using the Kodak Digital Image Analysis System (Kodak, New Haven, CT). The values obtained for each gene were normalized against $A C T B$. For each gene, at least three different normal cervix RNA samples were used to calculate the mean and SD. A gene was considered upregulated if the gene/control ratio was $\geq$ mean +2 SD of the normal cervix.
Oligonucleotide Microarray Gene Expression Analysis

Biotinylated cRNA preparation and hybridization to Affymetrix U133A oligonucleotide microarray (Affymetrix, Santa Clara, CA), which contains 14,500 genes was performed on 22 primary CC cases (only one of these cases was studied by aCGH), nine CG cell lines (eight were studied by aCGH), and 16 normal cervical epithelium specimens by the standard protocols supplied by the manufacturer. Arrays were subsequently developed and scanned to obtain quantitative gene expression levels. Expression values for the genes were determined using the Affymetrix GeneChip Operating Software (GCOS) and the Global Scaling option, which allows a number of experiments to be normalized to one target intensity to account for the differences in global chip intensity. To perform the supervised gene expression analysis, we used the Genes@Work software platform, which is a gene expression analysis tool based on the pattern discovery algorithm SPLASH (Structural Pattern Localization Analysis by Sequential Histograms) (Califano, 2000).

\section{Fluorescence In Situ Hybridization}

FISH was performed by standard methods on chromosomes prepared from eight CG cell lines. DNA prepared from human BAC clones RP11750P5 (11q22.2), RP11-480A16 (3q29), RP11$374 \mathrm{~B} 7$ (8q24.3), and RP11-30F23 (20q13.1) (Open Biosystems, Huntsville, Alabama) was labeled by nick-translation using spectrum red or spectrum green dUTP fluorochromes (Vysis, Downers Grove, IL). Spectrum red or spectrum green-labeled centromeric probes (CEP) were obtained from Vysis (Downers Grove, IL). Hybridization signals were scored on at least 20 metaphase spreads on DAPI counterstained slides.

\section{RESULTS}

Our previous molecular cytogenetic analyses of CG have identified complex chromosome alterations that include recurrent sites of high-level amplifications, $+3 \mathrm{q}$, and $\operatorname{del}(2 \mathrm{q})$ (Harris et al., 2003; Narayan et al., 2003b; Rao et al., 2004). To characterize this karyotypic complexity at the molecular level, we performed cDNA array $\mathrm{CGH}$ $(\mathrm{aCGH})$ analysis of a series of $29 \mathrm{CC}$ cases that included 8 cell lines and 21 primary tumor biopsies. Of these, 27 (91\%) were HPV positive (20 with HPV16/18; 7 harbored other HPV types) and two were HPV negative. Among the 9,206-cDNA 

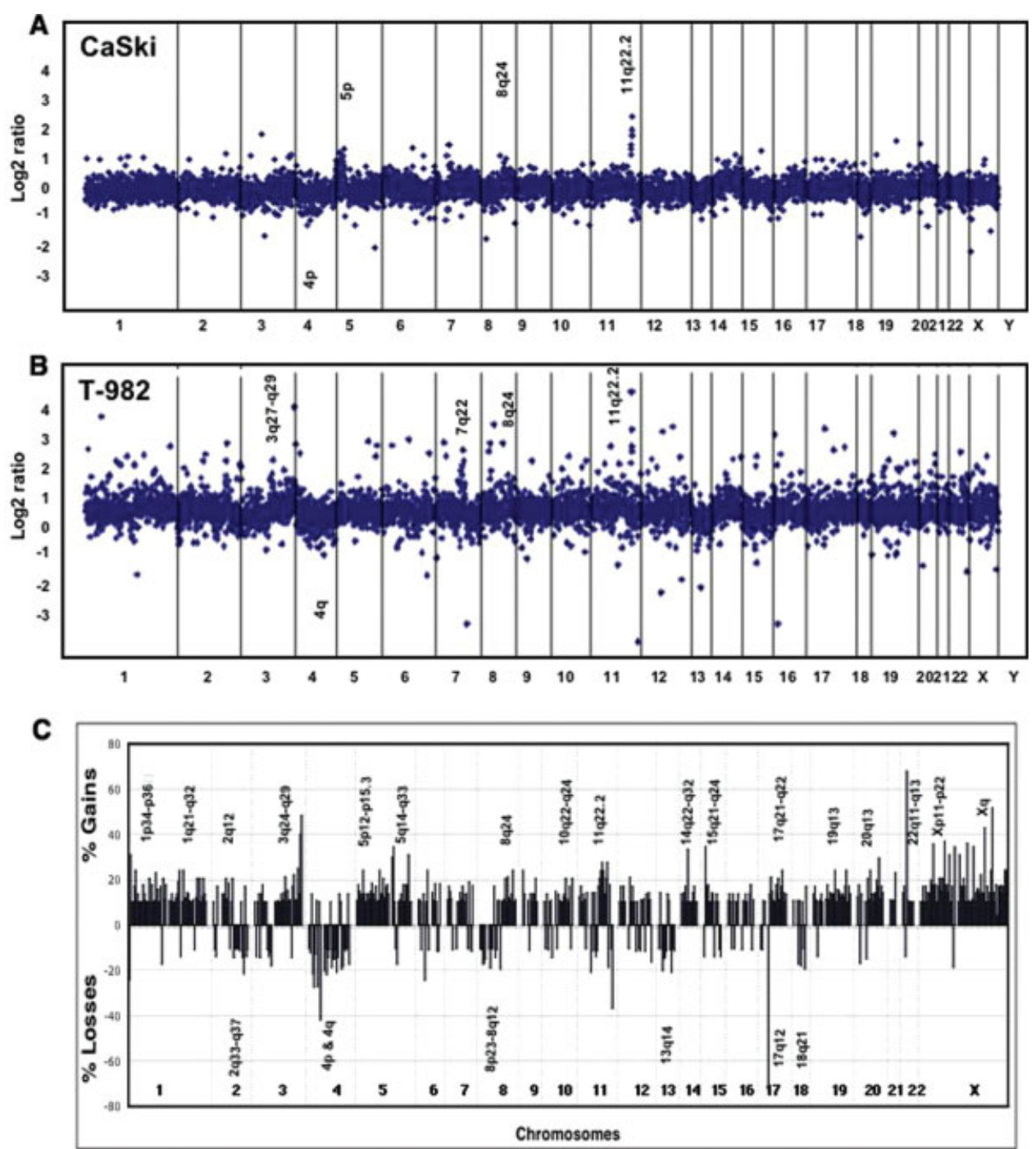

Figure I. Copy number alteration profiles in cervical cancer. Genomic changes in a representative cell line (A) and primary tumor (B) are shown. $\log _{2}$ ratios were plotted on the $Y$-axis for all clones on the array according to their map positions ( $X$-axis). (C) Frequency of copy number gains and losses ( $Y$-axis) based on their chromosomal map

sequences on the array, 445 (64.1 $\pm 35.2 /$ tumor) were found to be over represented and 121 (16.8 $\pm 13.9 /$ tumor) were deleted. A gene was considered either gained or lost if present in $>10 \%$ of tumors based on the criteria described in the methods. Although the frequency of gene copy number gains was similar in cell lines and primary tumors, deletions were more common in cell lines than in primary tumors $(28.4 \pm 16.1$ vs. $12.3 \pm$ 10.1; $P=0.003)$. Representative examples of genomic alteration profiles of a cell line (CaSki) and primary tumor (T-982) are shown in Figures $1 \mathrm{~A}$ and $1 \mathrm{~B}$. The data from the cell lines and primary tumors were combined in all subsequent analyses. position (X-axis) are shown. All of the clones that showed gain or loss in at least three tumors are used. Clones with information in less than $35 \%$ of tumors were excluded. Common regions of copy number gains and losses are indicated.

\section{Identification of Increased Gene Dosage Profiles}

The majority of the 445 cDNA clones with an increased dosage were mapped to few chromosomes, such as X (15\%), $1(13 \%), 5(9 \%), 3(6 \%), 19$ (6\%), and 20 (4\%) (Fig. 1C) (Supplementary Table 2A; supplementary material for this article can be found at http://www.interscience.wiley.com/jpages/ 1045-2257/suppmat). Therefore, the distribution of amplified clones in the chromosomal complement was nonrandom. The top 124 clones amplified in five or more tumors were associated with distinct cellular phenotypes, such as transcriptional regulation, cell cycle, cytoskeleton remodeling, apoptosis, angiogenesis, mitochondrial, ribosomal, immune 
TABLE I. Genes with Known Function Amplified in Five or More Tumors

\begin{tabular}{|c|c|c|c|}
\hline Gene & Function & Gene & Function \\
\hline Transcription factors & & \multicolumn{2}{|c|}{ Nuclear and lon transport } \\
\hline TFE3 & $\begin{array}{l}\text { Transcription factor binding to IGHM } \\
\text { enhancer } 3\end{array}$ & ATP7A & $\begin{array}{l}\text { ATPase, } \mathrm{Cu}^{2+} \text { transporting, } \alpha \\
\text { polypeptide }\end{array}$ \\
\hline TFAP2C & DNA-binding protein & OCLN & Regulation of the tight junction ( $\mathrm{TJ}$ ) \\
\hline SMARCD2 & $\begin{array}{l}\text { SWI/SNF related, matrix associated, } \\
\text { actin dependent regulator of } \\
\text { chromatin }\end{array}$ & RANBP2 & $\begin{array}{l}\text { paracellular permeability } \\
\text { Transport factor (RAN-GTP, } \\
\text { karyopherin)-mediated protein }\end{array}$ \\
\hline SMARCC2 & $\begin{array}{l}\text { SWI/SNF related, matrix associated, } \\
\text { actin-dependent regulator of } \\
\text { chromatin }\end{array}$ & $\begin{array}{l}\text { SCL9A6 } \\
\text { Cytoskeletal }\end{array}$ & $\begin{array}{l}\mathrm{Na}(+) \text { and } \mathrm{K}(+) \text { across the } \\
\text { mitochondrial inner membrane } \\
\text { raction }\end{array}$ \\
\hline ZNFI6I & $\begin{array}{l}\text { Binds to the CT/GC-rich region of the } \\
\text { interleukin-3 promoter } \\
\text { Zinc finger RNA binding protein }\end{array}$ & MSN & $\begin{array}{l}\text { Crosslinker between plasma } \\
\text { membranes and actin-based } \\
\text { cytoskeleton }\end{array}$ \\
\hline CTNNBLI & $\begin{array}{l}\text { Bipartite nuclear localization signal } \\
\text { and a leucine-isoleucine zipper }\end{array}$ & $\begin{array}{l}\text { MMPI } \\
\text { MPPI }\end{array}$ & $\begin{array}{l}\text { Interstitial collagenase } \\
\text { Membrane protein, palmitoylated }\end{array}$ \\
\hline $\begin{array}{l}\text { MYST2 } \\
\text { USP9X }\end{array}$ & $\begin{array}{l}\text { Histone acetyltransferase } \\
\text { Preventing degradation of proteins }\end{array}$ & ITGA2 & $\begin{array}{l}\text { Receptor for laminin, collagen, } \\
\text { collagen c-propeptides, fibronectin }\end{array}$ \\
\hline Apoptosis & & & and E-cadherin \\
\hline $\begin{array}{l}\text { MAP3K } 10 \\
\text { CASP4 }\end{array}$ & $\begin{array}{l}\text { Induction of apoptosis } \\
\text { Apoptosis-related cysteine protease; } \\
\text { promoter of apoptosis }\end{array}$ & MMP7 & $\begin{array}{l}\text { Degrades casein, gelatins, fibronectin, } \\
\text { and activates procollagenase } \\
\text { Control the properties of the }\end{array}$ \\
\hline PHLDA2 & $\begin{array}{l}\text { Implicated in Fas expression and } \\
\text { apoptosis }\end{array}$ & RDX & $\begin{array}{l}\text { membrane associated cytoskeleton } \\
\text { Binding of the barbed end of }\end{array}$ \\
\hline NALP2 & Apoptosis and inflammation & & actin filaments to the plasma \\
\hline Mitochondial & $\begin{array}{l}\text { Regulation of transcription from RNA } \\
\text { polymerase II promoter }\end{array}$ & EFNBI & $\begin{array}{l}\text { membrane } \\
\text { Binds to the receptor tyrosine } \\
\text { kinases }\end{array}$ \\
\hline Immune response & $\begin{array}{l}\text { Binding of initiation tRNA to } \\
\text { mitochondrial } 28 \text { S ribosomes }\end{array}$ & $\begin{array}{l}\text { COLI6AI } \\
\text { PTPRF }\end{array}$ & $\begin{array}{l}\text { Integrity of the extracellular matrix } \\
\text { Cell-matrix and cytoskeletal } \\
\text { rearrangements }\end{array}$ \\
\hline FYB & Adapter protein of the FYN and & \multicolumn{2}{|c|}{ Cell cycle, Mitotic check point, and DNA repair } \\
\hline IL7R & $\begin{array}{l}\mathrm{SH} 2 \text {-domain } \\
\text { Cytokine-cytokine receptor } \\
\text { interaction }\end{array}$ & $\begin{array}{l}\text { SMCILI } \\
\text { SEPT6 }\end{array}$ & $\begin{array}{l}\text { Chromosome cohesion during cell } \\
\text { cycle and in DNA repair } \\
\text { Cytokinesis }\end{array}$ \\
\hline IK & Downregulator of HLA II & RPS6 & Cell growth and proliferation \\
\hline ILI3RA2 & $\begin{array}{l}\text { Protein folding and intracellular } \\
\text { transport }\end{array}$ & $\begin{array}{l}\text { Ribosomal } \\
\text { SF3A3 }\end{array}$ & Binding of U2 snRNP to the \\
\hline IL2RG & $\begin{array}{l}\text { Protein folding and intracellular } \\
\text { transport }\end{array}$ & & $\begin{array}{l}\text { branchpoint sequence in pre- } \\
\text { mRNA }\end{array}$ \\
\hline CRI & $\begin{array}{l}\text { Complement component } \mathrm{C} 3 \mathrm{~b} \\
\text { receptor activity }\end{array}$ & SIAHBPI & $\begin{array}{l}\text { Fuse-binding protein-interacting } \\
\text { repressor }\end{array}$ \\
\hline Drug metabolism & Glutathione metabolism & RPS6KA3 & Phosphorylates substrates of \\
\hline GSTM2 & Glutathione metabolism & SNRPE & RNA binding \\
\hline
\end{tabular}

response, drug metabolism, and ion transport ('Table 1) (Supplementary Table 2B).

\section{Identification of Genes with Copy Number Deletions}

A total of $121 \mathrm{cDNAs}$ were under represented in the CG genome compared to normal (Fig. 1G). The under represented genes will be referred as deleted genes hereafter. The deleted cDNA clones were found to be preferentially localized to chromosomes 4 (21\%), 2 (11\%), 13q (8\%), 8 (8\%), 11 (7\%), 3p (5\%), and 12q (5\%). This nonrandom dis- tribution of deleted regions in the genome suggests that these chromosomal regions harbor candidate tumor suppressor genes relevant to $\mathrm{CC}$.

To identify common contiguous regions of deletions on the frequently affected chromosomes, we mapped in silico all of the deleted clones to exact sequence map positions using the NCBI's MapView genome browser (www.ncbi.nlm.nih.gov/ mapview/). This analysis identified 4q13.3 (3 Mb; 4 cDNA clones), 2q33-37 (36 Mb; 10 cDNA clones), 13q14.1 (8 Mb; 5 cDNA clones), 8p23 (6.2 $\mathrm{Mb} ; 3$ cDNA clones), 11q11.2-14 (27.2 Mb; 4 cDNA 
TABLE 2. List of 33 Genes with Known Function Deleted in Four or More Tumors

\begin{tabular}{|c|c|}
\hline Gene & Function \\
\hline \multicolumn{2}{|c|}{ Tumor suppressor genes } \\
\hline FHIT & $\begin{array}{l}\text { Cleaves A-5' }- \text { PPP-5'A to yield AMP } \\
\text { and ADP }\end{array}$ \\
\hline ZDHHC2 & $\begin{array}{l}\text { Mutated in hepatocellular and } \\
\text { colorectal cancer }\end{array}$ \\
\hline \multicolumn{2}{|c|}{ Transcription factors } \\
\hline SPIO0 & SPI00 nuclear antigen \\
\hline LDB2 & Neuronal and other development \\
\hline NFKBI & $\begin{array}{l}\text { Transcription factor, immune } \\
\text { response, apoptosis, and cell- } \\
\text { growth }\end{array}$ \\
\hline MEF2A & Transcription factor, muscle-specific \\
\hline ZNF20 & $\begin{array}{l}\text { Regulation of transcription, } \\
\text { DNA-dependent }\end{array}$ \\
\hline \multicolumn{2}{|c|}{ Pro-apoptosis } \\
\hline CASPI & $\begin{array}{l}\text { Promoter of apoptosis, interleukin } \\
\text { I- } \beta \text { specific }\end{array}$ \\
\hline \multicolumn{2}{|c|}{ Immune response } \\
\hline CCL4LI & $\begin{array}{l}\text { Immunoregulatory and inflammatory } \\
\text { processes }\end{array}$ \\
\hline FCGR3A & $\begin{array}{l}\text { Fc fragment of lgG, low affinity IIla, } \\
\text { receptor for (CDI6) }\end{array}$ \\
\hline GYPA & MN blood group receptors \\
\hline FGB & $\begin{array}{l}\text { Polymerization into fibrin and platelet } \\
\text { aggregation }\end{array}$ \\
\hline EMR3 & Immune and inflammatory responses \\
\hline \multicolumn{2}{|c|}{ DNA damage and repair } \\
\hline COPS8 & $\begin{array}{l}\text { Regulation of transcription in } \\
\text { response to DNA damage }\end{array}$ \\
\hline \multicolumn{2}{|c|}{ Cell-cell interaction } \\
\hline SPARCLI & $\begin{array}{l}\text { Antiadhesive extracellular matrix } \\
\text { property }\end{array}$ \\
\hline NRG I & $\begin{array}{l}\text { Ligand for ERBB3 and ERBB4 tyrosine } \\
\text { kinase receptors }\end{array}$ \\
\hline PICALM & $\begin{array}{l}\text { Mediating cell-adhesion to } \\
\text { extracellular matrix }\end{array}$ \\
\hline \multicolumn{2}{|c|}{ Miscellaneous genes } \\
\hline EVI5 & Ecotropic viral integration site 5 \\
\hline MCFD2 & $\begin{array}{l}\text { Multiple coagulation factor } \\
\text { deficiency } 2\end{array}$ \\
\hline TRAK2 & Trafficking protein, kinesin binding 2 \\
\hline MOBP & $\begin{array}{l}\text { Myelin-associated oligodendrocyte } \\
\text { basic protein }\end{array}$ \\
\hline GBEI & Glycogen biosynthesis \\
\hline GABRA2 & $\begin{array}{l}\text { Mediating inhibitory } \\
\text { neurotransmission }\end{array}$ \\
\hline UGT2B4 & Starch and sucrose metabolism \\
\hline SULTIEI & Androgen and estrogen metabolism \\
\hline METAPI & Methionyl aminopeptidase activity \\
\hline SNXI9 & Intracellular signaling \\
\hline GPRI09B & $\begin{array}{l}\text { G-protein coupled receptor signaling } \\
\text { pathway }\end{array}$ \\
\hline CPB2 & Carboxypeptidase activity \\
\hline TPP2 & Tripeptidyl-peptidase \\
\hline $\begin{array}{l}\text { MPI } \\
\text { ELACI }\end{array}$ & $\begin{array}{l}\text { Fructose and mannose metabolism } \\
\text { elaC homolog I }\end{array}$ \\
\hline $\mathrm{BCR}$ & $\begin{array}{l}\text { GTPase-activating protein, chronic } \\
\text { myeloid leukemia }\end{array}$ \\
\hline
\end{tabular}

clones), 3p14.2-21.3 (29 Mb; 4 cDNA clones) as commonly deleted sites. However, no minimal region could be derived from $12 \mathrm{q}$ due to dispersed deletions. A number of genes relevant to tumorigenesis maps to the minimal region of deletions. For example, the 2q33-37 regions contain at least two such genes, SMARCAL1 and COPS8. SMARCAL1 is an SWI/SNF related matrix-associated, actin-dependent regulator of chromatin, and COPS 8 plays a role in chromatin remodeling and DNA repair. The 8p23 deleted region contains CUB and Sushi multiple domains one (CSMD1) gene. The $8 \mathrm{p} 23$ region containing CSMD1 has been shown to be homozygously lost in tumors derived from bladder, colon, prostate, and fallopian tube (Blaveri et al., 2005). The 3p14-21 deletion spans the fragile histidine triad (FHIT) gene, which is deleted in multiple cancer types including CC (Sozzi et al., 1998). Of the 121 deleted genes, the top 52 clones with decreased copy numbers in four or more tumors include tumor suppressors (FHIT, ZDHHC2), and genes related to apoptosis (CASP1), transcription regulation, immune response (chemokine ligand 4-like 1; CCL4L1), cellcell interaction, and DNA repair (Table 2).

\section{Identification of Amplicons}

The nonrandom clustering of the majority of over represented clones in the dataset to a few chromosomal regions prompted us to use an objective criterion to identify and define the amplicons. Toward this end, all 445 amplified clones identified by aCGH were mapped in silico to specific chromosomal sites at the sequence level using the MapView browser (http://www.ncbi.nlm.nih.gov/ mapview/). A discrete locus of regional copy number increase represented by four or more clones within $15 \mathrm{Mb}$ genomic region in three or more tumors was considered a potential amplicon. This algorithm was highly effective as it identified 17 amplicons (four on X chromosome, three on chromosome 1 , and one each at chromosomal regions 3q27.3-29, 5p12-13, 5q31.3, 8q24.3, 11q22-23, $14 \mathrm{q} 32,17 \mathrm{q} 21-22,19 \mathrm{p} 13,19 \mathrm{q} 13.3$, and $20 \mathrm{q} 13.1$ ) (Table 3). A number of recurrent over represented cDNA clones, however, remained single genes at their specific chromosomal regions, which requires further confirmation by other methods.

\section{Expression-Array Validation of Genes in Amplicons}

In the present study, we restricted the validation to the genes present within the 17 amplicons identified above. To identify expression profiles of the genes within the amplicons, we used the Affymetrix U133A array data sets derived from 16 normal 
TABLE 3. Identification of Amplicons in Cervical Cancer and Genes Present in the Amplicons

\begin{tabular}{|c|c|c|c|c|c|}
\hline \multirow[b]{2}{*}{ Amplicon } & \multirow[b]{2}{*}{$\begin{array}{l}\text { Size } \\
(\mathrm{Mb})\end{array}$} & \multirow[b]{2}{*}{$\begin{array}{l}\text { Amplified } \\
\text { region (kb) }\end{array}$} & \multirow[b]{2}{*}{$\begin{array}{l}\text { aCGH array } \\
\text { amplified genes }\end{array}$} & \multicolumn{2}{|r|}{ Genes overexpressed on affymetrix array } \\
\hline & & & & No. & $\begin{array}{l}\text { Selected genes of importance to } \\
\text { tumorigenesis }\end{array}$ \\
\hline Ip36 & 10.5 & $15640-25843$ & MSTP9, TCEA3 & 13 & $\begin{array}{l}\text { SPEN, CROCC, PADI3, KIAA0090, } \\
\text { CaMKIIN } \alpha \text {, EIF4G3, EPHB2, HNRPR, ID3, } \\
\text { AD7c-NTP, TCEB3, FUSIPI, RUNX3 }\end{array}$ \\
\hline Ip34 & 8.0 & $31576-39695$ & $\begin{array}{l}\text { TDE2L, COLI6AI, RBBP4, } \\
\text { ZNF258, SF3A3, PABPC4 }\end{array}$ & 12 & $\begin{array}{l}\text { LCN7, PTP4A2, TMEM39B, KPNA6, } \\
\text { MARCKSLI, FLJI 0276, RBBP4, YARS, } \\
\text { AK2, CDCA8, FLJI2666, PABPC4 }\end{array}$ \\
\hline Iq22-q23 & 6.6 & $1558 \mid 5-162367$ & IFII 6, APCS, NHLHI, DDR2 & 6 & $\begin{array}{l}\text { IFII 6, AIM2, PFDN2, HSPA6, FCGR3B, } \\
\text { DUSPI } 2\end{array}$ \\
\hline $3 q 27-q 29$ & 11.8 & $|8539|-197 \mid 97$ & ABCF3, SENP2, RFC4 & 20 & $\begin{array}{l}\text { ALG3, PSMD2, POLR2H, MAGEFI, IMP-2, } \\
\text { ETV5, RFC4, SIATI, RPL39L, IFRG28, } \\
\text { FLJ42393, ILIRAP, HRASLS, OPAI, HESI, } \\
\text { ATPI I3A3, FLJI I 30I, FLJ43227, MUC4, } \\
\text { Hs. I } 24620\end{array}$ \\
\hline $5 p|2-p| 3$ & 11.6 & $32161-43740$ & $\begin{array}{l}\text { NNT, FYB, NIPBL, IL7R, } \\
\text { AGXT2, ZFR, GOLPH3 }\end{array}$ & 13 & $\begin{array}{l}\text { GOLPH3, TARS, RADI, SKP2, SLCIA3, } \\
\text { NIPBL, NUPI55, OSMR, FYB, PRKAAI, } \\
\text { Hs.449869, PAIPI, NNT }\end{array}$ \\
\hline $5 q 31.3$ & 1.3 & $|4002|-|4| 37 \mid$ & IK, TAF7, GNPDAI & 2 & DIAPHI, CENTD3 \\
\hline $8 q 24.3$ & 4.6 & $14 \mid 599-146047$ & $\begin{array}{l}\text { EIF2C2, PTK2, SIAHBPI, } \\
\text { DGAT I, COMMD5 }\end{array}$ & 14 & $\begin{array}{l}\text { EIF2C2, PTK2, LOC5 I337, LY6E, } \\
\text { EXOSC4, GPAAI, CYCI, BOPI, DGATI, } \\
\text { GPRI72A, CPSFI, SLC39A4, RECQL4, } \\
\text { LRRCI4 }\end{array}$ \\
\hline I Iq22.2 & 0.8 & $102137-102955$ & $\begin{array}{l}\text { MMP7, MMPI, MMPI } 2 \\
\text { MMPI 3, YAPI }\end{array}$ & 9 & $\begin{array}{l}\text { BIRC2, BIRC3, PORIMIN, MMP7, MMPI0, } \\
\text { MMPI, MMP3, MMPI 2, MMPI } 3\end{array}$ \\
\hline $14 q 32.33$ & 4.0 & $102265-106330$ & RCORI, TNFAIP2 & 16 & $\begin{array}{l}\text { CDC42BPB, TNFAIP2, EIF5, KNS2, BAG5, } \\
\text { XRCC3, SIVA, AKTI, CDCA4, JAG2, } \\
\text { BRFI, PACSIL, MTAI, CRIPI, IGHM, } \\
\text { Hs.4490II }\end{array}$ \\
\hline$|7 q 2|-q 22$ & 9.8 & $44024-53809$ & PHB, SPOP, MYST2, ZNFI6I & 7 & $\begin{array}{l}\text { HOXB7, ITGA3, ABCC3, CROP, NME2, } \\
\text { MMD, AKAPI }\end{array}$ \\
\hline $19 p 13.13$ & 5.4 & $10265-15668$ & $\begin{array}{l}\text { ICAM5, KLFI, PRKACA, } \\
\text { CYP4FI } 2\end{array}$ & 17 & $\begin{array}{l}\text { FLJI I 286, TYK2, FLJ I 2949, ILF3, SMARCA4, } \\
\text { PRKCSH, TNPO2, RNASEH2A, DNASE2, } \\
\text { RAD23A, Hs.293379, FLJ20244, BTBD I4B, } \\
\text { FLJ23447, ASFIB, DDX39, BRD4 }\end{array}$ \\
\hline $19 q 13.3$ & 14.4 & $45390-59790$ & $\begin{array}{l}\text { ARHGEFI, GRLFI, DHX34, } \\
\text { LIG I, SNRP70, PRKCG, } \\
\text { LILRBI }\end{array}$ & 46 & $\begin{array}{l}\text { SNRPA, EGLN2, HNRPULI, FLII024I, ERF, } \\
\text { PAFAHIB3, PLAUR, KCNN4, PVR, BCL3, } \\
\text { CBLC, LU, APOCI, ERCC2, RTN2, } \\
\text { SYMPK, PPP5C, PRKD2, STRN4, SLCIA5, } \\
\text { SAEI, KPTN, LIGI, KDELRI, RASIPI, } \\
\text { BCAT2, BAX, RUVBL6, TRPM4, NOSIP, } \\
\text { IRF3, HRMTIL2, PNKP, NUP62, ATF5, } \\
\text { VRK3, ZNF473, POLDI, ETFB, ZNF6II, } \\
\text { ZNFI60, PRPF3I, CNOT3, LENG4, } \\
\text { LENG5, LILRB3 }\end{array}$ \\
\hline $20 q \mid 3.1$ & 2.6 & $42683-45242$ & $\begin{array}{l}\text { ADA, YWHAB, SLPI, } \\
\text { EYA2 }\end{array}$ & 12 & $\begin{array}{l}\text { ADA, YWHAB, TOMM34, STK4, KCNSI, } \\
\text { SDC4, PIGT, ZNF335, UBE2C, MMP9, } \\
\text { CD40, EYA2 }\end{array}$ \\
\hline XpII.2-pII.3 & 7.5 & $47188-54924$ & $\begin{array}{l}\text { ALAS2, SMCILI, PLP2, } \\
\text { T54,TFE3, SSX3, UXT, } \\
\text { TIMPI }\end{array}$ & 5 & TIMPI, PQBPI, WDR45, SMCILI, GNL3L \\
\hline $\mathrm{Xq} / 2$ & 6.8 & $67539-74307$ & $\begin{array}{l}\text { EFNBI, IL2RG, ITGBIBP2, } \\
\text { OGT, SLCI6A2 }\end{array}$ & 2 & KIF4A, SEPHSI \\
\hline $\mathrm{Xq22}$ & 2.2 & $100459-10269 \mid$ & GLA, ALEX3, PLPI, TCEALI & 2 & TMSNB, PRKCI \\
\hline $\mathrm{Xq} 28$ & 5.6 & $|48342-154| 07$ & $\begin{array}{l}\text { MAGEAI0, NSDHL, IDH3G, } \\
\text { PLXN3, MPPI }\end{array}$ & 13 & $\begin{array}{l}\text { HMGB3, MAGEA3, MAGE6, CSAG2, TREX2, } \\
\text { DUSP9, SLC6A8, SLC6AI0, ARHGAP4, } \\
\text { IRAKI, G6PD, DKCI, F8AI }\end{array}$ \\
\hline
\end{tabular}

Genes shown in bold are commonly found in both aCGH and Affymeterix arrays. 
cervical epithelium samples and 31 CC cases (unpublished data). Only nine cases (one primary tumor and eight cell lines) were commonly studied by both aCGH and Affymeterix expression profiling studies due to limitations in obtaining good quality RNA. First, we identified all of the probe sets present in the U133A array within the genomic intervals of all 17 amplicons using AffymetrixUCSC Genome Browser Query Tool (www.affymetrix.com/analysis/netaffx/query_ucsc.affx?mapping). As expected, this analysis identified a large number of genes in each of the amplicons (data not shown). These probe sets were examined in the normalized expression profiles derived from normal cervix and invasive CC to identify over expressed genes. A gene was considered over expressed if the expression levels exceeded mean $+2 \mathrm{SD}$ of normal in $>10 \%$ tumors. This analysis identified a number of overexpressed genes in each of the amplicons: $1 \mathrm{p} 36,13 ; 1 \mathrm{p} 34,12 ; 1 \mathrm{q} 22-23,6$; 3q27-29, 21; 5p1213, 13; 5q31.3, 2; 8q24.3, 14; 11q22.2, 9; 14q32.33, $16 ; 17 \mathrm{q} 21-22,7 ; 19 \mathrm{p} 13.13,17 ; 19 \mathrm{q} 13.3,46 ; 20 \mathrm{q} 13.1$, 12; Xp11.2-11.3, 5; Xq12, 2; Xq22, 2; and Xq28, 13 (Table 3; Supplementary Table 3A; supplementary material for this article can be found at http://www. interscience.wiley.com/jpages/1045-2257/suppmat).

\section{RT-PCR Validation of Genes Overexpressed by Array Expression Analysis}

To further validate the genes that showed evidence of over expression by Affymetrix expression profiles, we chose one to three genes functionally relevant in tumor development in each of the focal amplicons and analyzed them by semiquantitative RT-PCR. Thus, a total of 23 genes that mapped to 17 amplicons were examined by RT-PCR in 8 normal cervical epithelium, 9 CC cell lines, and 10 primary tumors. These analyses showed that all genes tested, except PTPA2 at $1 \mathrm{p} 34$ and $H M G B 3$ at $\mathrm{Xq} 28$, showed similar levels of increased expression in tumors compared to the corresponding normal cervix (Supplementary Table 3B). Thus, in a subset of tumors, the overexpression of genes within amplicons was confirmed by both Affymeterix expression and RT-PCR analyses, which showed a similar fold increase (Fig. 2, and supplementary Table 3B). RTPCR analysis of CDCA8, AIM2, ABCC3, RECQL4, SMARCA4, and CSAG2 genes showed no detectable levels of expression in normal cervix and the fold increase for these genes in tumor specimens was considered $100 \%$ (Fig. 2). Thus, using two different validation methods, we showed overexpression of a number of genes mapped within the amplicons identified by aCGH array.

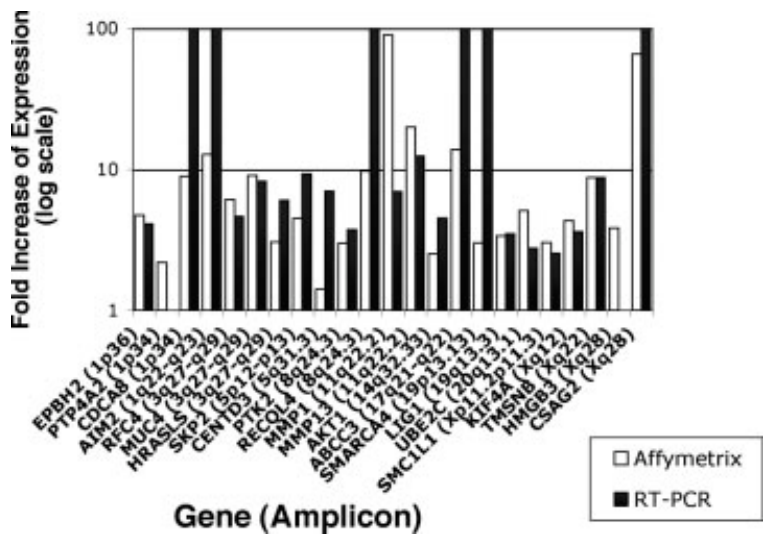

Figure 2. Comparison of expression levels by Affymeterix microarray and semiquantitative RT-PCR analyses of genes mapped to various amplicons in CC. Fold increase was calculated based on averages obtained for a given gene in all normals analyzed and only tumors that showed evidence of overexpression using the criteria defined in Materials and Methods. Note that the genes (CDCA8, AIM2, RECQL4, ABCC3, and SMARCA4) that did not show detectable expression in normal cervix by RT-PCR were considered as 100 -fold overexpressed in tumors. Two genes (PTP4A2 and HMGB3) showed no increased levels of expression by RT-PCR in tumors compared to normal cervix.

\section{FISH Validation of Amplicons}

Four of the amplicons (3q27.3-29, 8q24.3, 11q22.2, and 20q13.1) have been further examined by FISH to assess genomic copy number increase in eight CC cell lines. FISH analysis using RP11480A16 BAC clone containing the SDHA-like gene at 3q29 showed four or more copies in three of the eight CC cell lines tested (Fig. 3A). By FISH analysis of a BAC clone RP11-374B7 mapped $2 \mathrm{Mb}$ proximal to the 8q24.3 amplicon we found a homogeneously staining region (hsr) present on three different chromosomes in the SW756 cells (Fig. 3B). Three other cell lines (HT-3, MS751, and CaSki) showed 4-6 copies of signals. The 11q22.2 amplicon was studied using a BAC clone RP11-750P5 containing the MMP1, MMP10, $M M P 8$, and MMP27 genes. We showed evidence of hsr-type amplification in two of eight cell lines. The cell line CaSki showed three copies of chromosome 11 containing highly amplified regions and C-4I had two amplified segments also on chromosome 11 (Fig. 3C). Both of these cell lines also exhibited amplification by aCGH analysis. A third cell line, HT-3, had four copies of the signal. The remaining five cell lines had only $2-3$ copies of the signals. The 20q13.1 amplicon was tested by using RP11-30F23, which covers a region that is located approximately $200 \mathrm{~kb}$ distal to the YWHAB/14-3-3$\beta$ gene. Hsr-type amplification of this region was found in the HT-3 cell line and 4-7 copies of signals were seen in SW756, SiHa, CaSki, and MS751 cell lines (Fig. 3D). 


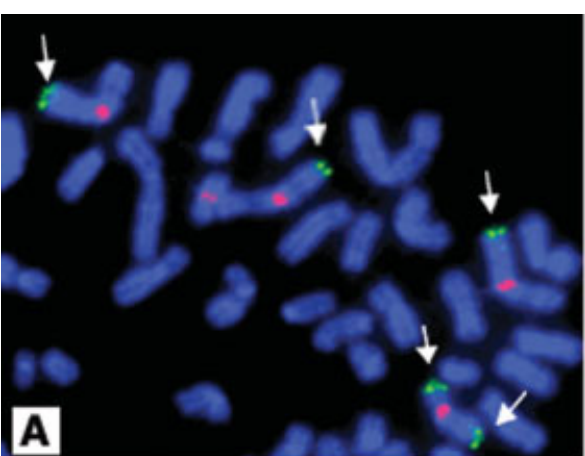

RP11-480A16/3q29

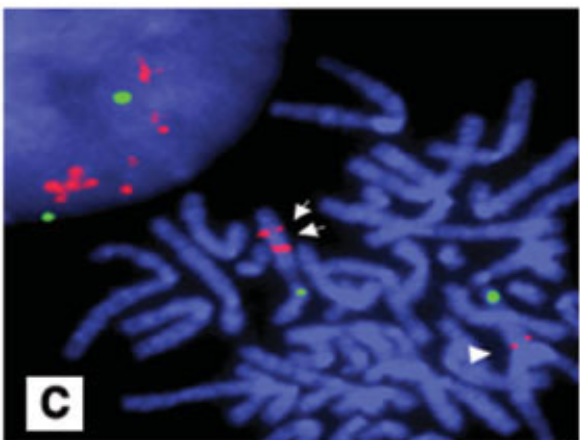

RP11-750P5/11q22.2

Figure 3. Validation of amplicons by FISH analysis on CC cell lines. (A) Identification of increased copies of signals of the BAC clone RPI I480A 16 mapped to 3q27.3-q29 amplicon in cell line CaSki. Probe signals indicated by thin arrows (green). Red signals indicate chromosome 3 centromere. (B) Identification of 8q24.3 amplification in cell line SW756 using RPII-374BI7 BAC clone. Note the presence of three copies of large and amplified signals (Red) (large arrow heads) and one normal size signal (thin arrow). Green signals represent chromosome 8 centromere. (C) Illustration of I I 22.2 amplification using a BAC clone RPI I-

\section{DISCUSSION}

Like many other epithelial cancers, invasive CC exhibits complex chromosomal changes (Atkin, 1997; Harris et al., 2003; Rao et al., 2004). The molecular consequence of this genomic complexity is poorly understood. Extensive genome-wide LOH studies have shown allelic deletions of chromosome arms 2q, 3p, 4, 5p, 6p, and 11q (Mitra et al., 1994a; Mullokandov et al., 1996; Narayan et al., 2003b). A number of studies have provided evidence for gain or amplification of chromosomal regions or genes (Mitra et al., 1994b; Heselmeyer et al., 1996; Narayan et al., 2003b; Rao et al., 2004). Gene dosage changes play a major role in tumor formation and progression (Albertson et al., 2003). The analyses presented here identified several such gene dosage alterations in CC. The copy number changes identified by aCGH showed a near concordance with the previously reported chromosomal CGH (cCGH) data on the same panel of tumors validating the present data (Harris

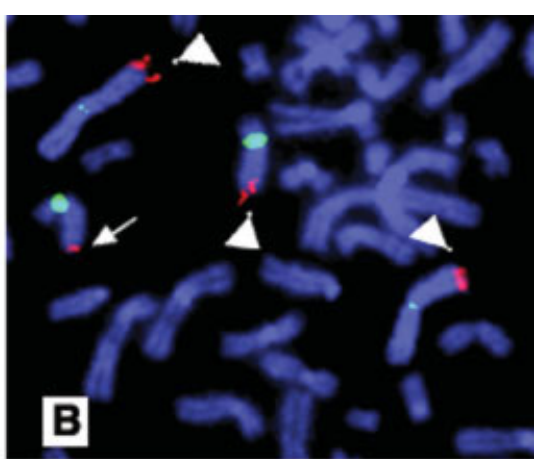

RP11-347B17/8q24.2

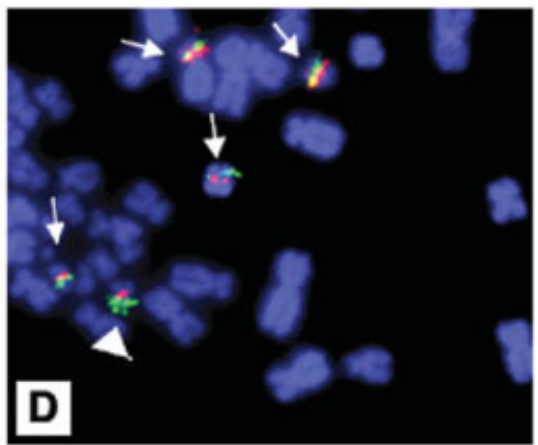

RP11-30F23/20q13

750 P5 (Red) mapped to this amplicon in cervical cancer cell lines. C-4I cell line showing two segments of amplification on the same chromosome. Thin arrows show amplified signals and the arrowheads indicate normal signals. Green signals represent chromosome II centromere. (D) Identification of 20q amplification in HT-3 cell line using RPII30F23 BAC clone. Large arrowhead represents amplified copies of the clone mapped to $20 \mathrm{q} 13.1$ (Green). Small arrows indicated normal signals. Red signal represents chromosome 20 centromere.

et al., 2003; Narayan et al., 2003b; Rao et al., 2004). Comparing the recurrent increased copy number of one or more cDNA clones by aCGH in the present study with those of the cCGH data showed common amplifications that correspond to the regions 1p31, 2q32, 7q22, 8q21-q24, 10q23, 11q22, 16q23q24, 20q11.2, 20q13.1, and Xp (Fig. 4A). Analysis of these data sets also showed similar concordance of chromosomal gains at 1p, 3q, 5p, 9q, 14q, 17q, and X (Fig. 4A). In addition, analysis of the data on deletions showed a similar correlation between the cCGH and aCGH with common regions of deletions at 2q33-37, 3p, 4p, 6q, 8p, 10p, 11q22-25, $13 q$, and $18 \mathrm{q}$ (Fig. 4B). However, the chromosomal amplifications at $7 \mathrm{p} 11.2,10 \mathrm{q} 21,11 \mathrm{q} 13$, and $12 \mathrm{q} 15$ regions revealed by cCGH could not be confirmed by aCGH (Fig. 4A). This discrepancy between cCGH and aCGH data may be due to the differences in coverage by each of the techniques. Although cCGH will identify all of the genomic changes at a resolution of megabase level, the array 
NARAYAN ET AL.
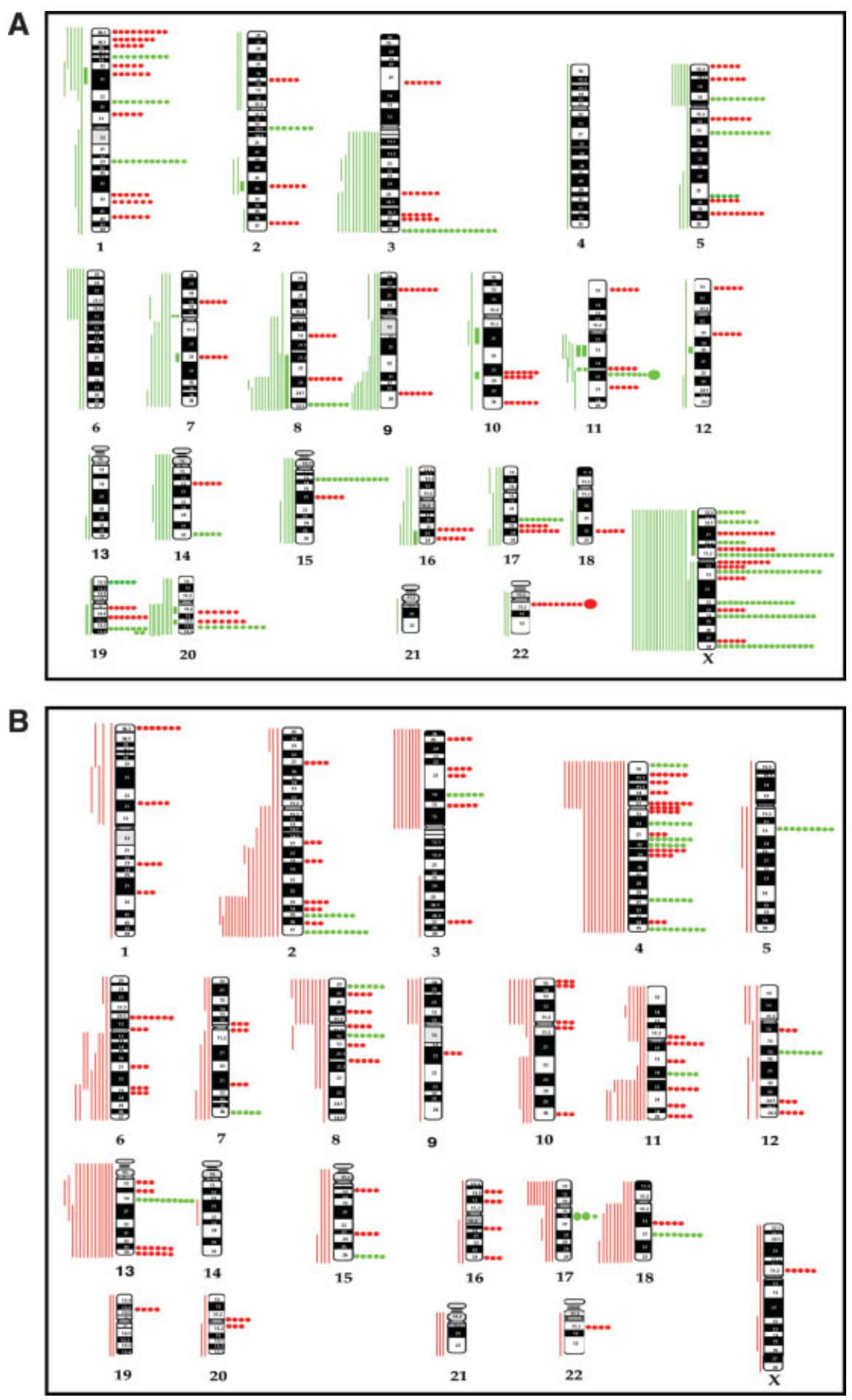

Figure 4. Ideogram showing correlation of chromosome copy number alterations identified by $\mathrm{CCGH}$ and aCGH in 29 cervical cancer specimens. (A) Copy number gains and amplifications. CCGH data are shown in green vertical lines on left of the ideogram. Thin vertical lines indicate gains. Thick vertical lines indicate high-level amplifications. The aCGH data on increased copy number of clones is shown on the right of the ideogram in circles. Each small circle represents one tumor. Large circles represent 10 tumors. Green circles represent increased copies

of multiple clones within the chromosomal sub-band, while the red circles represent a single clone. (B) Copy number deletions. Deletions identified by cCGH are shown in red vertical lines on left of the ideogram. The aCGH data on decreased copy number of clones is shown on the right of ideogram in circles. Each circle represents one tumor. Large circles represent 10 tumors. Green circles represent deletion of multiple clones within the chromosomal sub-band, while the red circles represent a single clone. 
we used for aCGH has only an average coverage of $300 \mathrm{~kb}$. Since the cDNA array used by us had low genomic representations in certain regions of the genome, we assume that genomic regions of some of the amplicons identified by cCGH are under represented in the cDNA array. Second, the criteria that we applied to identify amplifications at aCGH analysis in the present study will be eliminated amplifications present in less than three tumors.

The amplification of oncogenes is a known genetic mechanism underlying the development of a number of tumor types. Our previous studies suggested that gene amplification is a common event in CC (Mitra et al., 1994b; Harris et al., 2003; Narayan et al., 2003b). The present analysis identified increased copy number of cDNA clones on the entire X chromosome suggesting gain of this chromosome (Rao et al., 2004). The gain of 3q26-29 has been commonly reported in invasive CC and was shown to occur during the progression from low- to high-grade cervical intraepithelial neoplasia (CIN) (Heselmeyer et al., 1996; Heselmeyer-Haddad et al., 2003; Hidalgo et al., 2005; Narayan et al., 2003b; Rao et al., 2004; Fitzpatrick et al., 2006). Here we identified an amplicon spanning $11.8 \mathrm{Mb}$ in $3 \mathrm{q} 27.3-29$. Gain of distal $3 \mathrm{q}$ is commonly seen in many other tumor types, such as head and neck squamous-cell carcinomas, and lung and ovarian cancer. Potential target oncogenes at 3q26-29 such as PIK3CA, TP73L, CCNL1, and EIF5A2 have been reported (Redon et al., 2002). Previous studies have implicated PIK3CA and TERC as target genes in CG (Ma et al., 2000; Sugita et al., 2000; Heselmeyer-Haddad et al., 2003). Mapped to 3q26.3, these genes are, however, $10 \mathrm{Mb}$ proximal to the $3 \mathrm{q}$ amplicon identified in the present study. The 3q27.3-29 region contains several genes of relevance to cancer (Table 3). We showed here a 2.5 to 10.9 -fold increased expression of three genes (RFCA, MUCA, and HRASLS) by both microarray expression profiles and RT-PCR (Fig. 2). RFC4 (replication factor 4) plays a critical role in DNA damage checkpoint pathways (Ellison and Stillman, 2003). Mucin 4 (MUC4) secreted by epithelial surfaces including cervix is implicated in renewal and differentiation of these cells. MUC4 has been reported to be overexpressed in pancreatic cancer and cervical dysplasias, and acts as ligand for ERBB2 and a target for the TGFB pathway (Lopez-Ferrer et al., 2001; Jonckheere et al., 2004; Singh et al., 2004). The mouse homologue of HRASLS encodes a ras-responsive gene, which modulates the HRAS-mediated signaling pathway.
Amplicons at $8 \mathrm{q} 24.3$ and $20 \mathrm{q} 13.1$ have been found in many tumor types, including CC (Zhang et al., 2002; Hodgson et al., 2003). The 8q24 region harbors a number of genes including $M Y C$. In the present study, two genes, PTK2 and RECQL4, mapped to this amplicon were examined and shown to exhibit 3 to $>9.7$-fold increased expression in CG. The protein tyrosine kinase 2 (PTK2) gene, which encodes a cytoplasmic protein tyrosine kinase, is implicated in signaling pathways involved in cell motility, proliferation, and apoptosis (McLean et al., 2005). The RecQ protein-like 4 (RECQL4) encodes a DNA helicase involved in the maintenance of genomic integrity (Hickson, 2003). No report of RECQL4 amplification and/or over expression in human cancer is known thus far and it remains to be seen whether the over expression of RECQL4 has any functional role in CC tumorigenesis or represents a bystander affect. The 20q13.1 region, known to be amplified in diverse tumor types, harbors several genes implicated in tumorigenesis, such as AIB1, BTAK, and PTPN1. Our Affymetrix gene expression profiles identified increased expression of 12 genes, including $U B E 2 C$, within the $20 \mathrm{q} 13.1$ amplicon. Of these, the overexpression of $U B E 2 C$ gene was further confirmed by RT-PCR analysis (Fig. 2). Ubiquitinconjugating enzyme E2C (UBE2C) encodes a member of the E2 ubiquitin-conjugating enzyme family, which is essential for destruction of mitotic cyclins and for cell cycle progression. The ubiquitin-conjugase family genes are amplified and overexpressed in many human tumors, including CC (Wagner et al., 2004; Santin et al., 2005). The present study also identified a number of previously uncharacterized amplifications, which could include genes relevant to CC that may be revealed by positional approaches. For instance, the $820 \mathrm{~kb}$ 11q22.2 amplicon contains a number of matrix metalloproteinase (MMPs 1, 3, 12, and 13) genes, which are known to be overexpressed in many tumor types and that promote tumor growth, cell proliferation, and migration (Overall and LopezOtin, 2002).

This work represents the first high-resolution aCGH analysis of CG, which forms a basis for further studies on a subset of candidate genes in delineating the molecular mechanisms involved in its development. Identification of tumor-specific gene dosage profiles has important potential diagnostic and therapeutic implications. The distinct genetic losses and gains seen in the present study may be characteristic of $\mathrm{CC}$ as some of these changes (e.g., gain of $5 \mathrm{p}, 5 \mathrm{q}$, and loss of $2 \mathrm{q}, 4 \mathrm{p}, 4 \mathrm{q})$ are not commonly seen in 
other epithelial cancers. Detailed characterization of the amplified and deleted regions may facilitate the identification and functional characterization of genes involved in CC development. In addition, examination of these changes in CIN lesions may provide new insights into the role of these genes in the progression of CC and thus in the diagnostic identification of lesions at high-risk for progression into invasive cancer.

\section{REFERENCES}

Albertson DG, Collins C, McCormick F, Gray JW. 2003. Chromosome aberrations in solid tumors. Nat Genet 34:369-376.

Atkin NB. 1997. Cytogenetics of carcinoma of the cervix uteri: a review. Cancer Genet Cytogenet 95:33-39.

Blaveri E, Brewer JL, Roydasgupta R, Fridlyand J, DeVries S, Koppie T, Pejavar S, Mehta K, Carroll P, Simko JP, Waldman FM. 2005. Bladder cancer stage and outcome by array-based comparative genomic hybridization. Clin Cancer Res 11:7012-7022.

Bourdon V, Naef F, Rao PH, Reuter V, Mok SC, Bosl GJ, Koul S, Murty VV, Kucherlapati RS, Chaganti RS. 2002. Genomic and expression analysis of the 12p11-p12 amplicon using EST arrays identifies two novel amplified and overexpressed genes. Cancer Res 62:6218-6223.

Califano A. 2000. SPLASH: Structural pattern localization analysis by sequential histograms. Bioinformatics 16:341-357.

Cappellen D, De Oliveira C, Ricol D, de Medina S, Bourdin J, Sastre-Garau X, Chopin D, Thiery JP, Radvanyi F. 1999. Frequent activating mutations of FGFR3 in human bladder and cervix carcinomas. Nat Genet 23:18-20.

Chatterjee A, Pulido HA, Koul S, Beleno N, Perilla A, Posso H, Manusukhani M, Murty VV. 2001. Mapping the sites of putative tumor suppressor genes at $6 \mathrm{p} 25$ and $6 \mathrm{p} 21.3$ in cervical carcinoma: Occurrence of allelic deletions in precancerous lesions. Cancer Res 61:2119-2123.

Ellison V, Stillman B. 2003. Biochemical characterization of DNA damage checkpoint complexes: Clamp loader and clamp complexes with specificity for 5' recessed DNA. PLoS Biol 1:E33.

Fitzpatrick MA, Funk MC, Gius D, Huettner PC, Zhang Z, Bidder M, Ma D, Powell MA, Rader JS. 2006. Identification of chromosomal alterations important in the development of cervical intraepithelial neoplasia and invasive carcinoma using alignment of DNA microarray data. Gynecol Oncol 103:458-462.

Harris CP, Lu XY, Narayan G, Singh B, Murty VV, Rao PH. 2003. Comprehensive molecular cytogenetic characterization of cervical cancer cell lines. Genes Chromosomes Cancer 36:233-241.

Heselmever K, Schrock E, du Manoir S, Blegen H, Shah K, Steinbeck R, Auer G, Ried T. 1996. Gain of chromosome 3q defines the transition from severe dysplasia to invasive carcinoma of the uterine cervix. Proc Natl Acad Sci USA 93:479-484

Heselmeyer-Haddad K, Janz V, Castle PE, Chaudhri N, White N, Wilber K, Morrison LE, Auer G, Burroughs FH, Sherman ME, Ried T. 2003. Detection of genomic amplification of the human telomerase gene (TERC) in cytologic specimens as a genetic test for the diagnosis of cervical dysplasia. Am J Pathol 163:14051416.

Hickson ID. 2003. RecQ helicases: Caretakers of the genome. Nat Rev Cancer 3:169-178.

Hidalgo A, Baudis M, Petersen I, Arreola H, Pina P, Vazquez-Ortiz G, Hernandez D, Gonzalez J, Lazos M, Lopez R, Perez C, Garcia J, Vazquez K, Alatorre B, Salcedo M. 2005. Microarray comparative genomic hybridization detection of chromosomal imbalances in uterine cervix carcinoma. BMC Cancer 5:77.

Hodgson JG, Chin K, Collins C, Gray JW. 2003. Genome amplification of chromosome 20 in breast cancer. Breast Cancer Res Treat 78:337-345.

Jonckheere N, Perrais M, Mariette C, Batra SK, Aubert JP, Pigny P, Van Seuningen I. 2004. A role for human MUC4 mucin gene, the ErbB2 ligand, as a target of TGF- $\beta$ in pancreatic carcinogenesis. Oncogene 23:5729-5738.

Kersemaekers AM, van de Vijver MJ, Kenter GG, Fleuren GJ. 1999. Genetic alterations during the progression of squamous cell carcinomas of the uterine cervix. Genes Chromosomes Cancer 26:346354.
Lopez-Ferrer A, Alameda F, Barranco C, Garrido M, de Bolos C. 2001. MUC4 expression is increased in dysplastic cervical disorders. Hum Pathol 32:1197-1202.

Ma YY, Wei SJ, Lin YC, Lung JC, Chang TC, Whang-Peng J, Liu JM, Yang DM, Yang WK, Shen CY. 2000. PIK3CA as an oncogene in cervical cancer. Oncogene 19:2739-2744.

McLean GW, Carragher NO, Avizienyte E, Evans J, Brunton VG, Frame MC. 2005. The role of focal-adhesion kinase in cancer-a new therapeutic opportunity. Nat Rev Cancer 5:505-515.

Mitra AB, Murty VV, Li RG, Pratap M, Luthra UK, Chaganti RS. 1994a. Allelotype analysis of cervical carcinoma. Cancer Res 54:4481-4487.

Mitra AB, Murty VV, Pratap M, Sodhani P, Chaganti RS. 1994b. ERBB2 (HER2/neu) oncogene is frequently amplified in squamous cell carcinoma of the uterine cervix. Cancer Res 54:637639.

Mullokandov MR, Kholodilov NG, Atkin NB, Burk RD, Johnson AB, Klinger HP. 1996. Genomic alterations in cervical carcinoma: Losses of chromosome heterozygosity and human papilloma virus tumor status. Cancer Res 56:197-205.

Narayan G, Arias-Pulido H, Koul S, Vargas H, Zhang FF, Villella J, Schneider A, Terry MB, Mansukhani M, Murty VV. 2003a. Frequent promoter methylation of CDH1, DAPK, RARB, and HIC1 genes in carcinoma of cervix uteri: Its relationship to clinical outcome. Mol Cancer 2:24.

Narayan G, Pulido HA, Koul S, Lu XY, Harris CP, Yeh YA, Vargas H, Posso H, Terry MB, Gissmann L, Schneider A, Mansukhani M, Rao PH, Murty VV. 2003b. Genetic analysis identifies putative tumor suppressor sites at 2q35-q36.1 and 2q36.3-q37.1 involved in cervical cancer progression. Oncogene 22:3489-3499.

Overall CM, Lopez-Otin C. 2002. Strategies for MMP inhibition in cancer: Innovations for the post-trial era. Nat Rev Cancer 2:6576572.

Pollack JR, Perou CM, Alizadeh AA, Eisen MB, Pergamenschikov A, Williams CF, Jeffrey SS, Botstein D, Brown PO. 1999. Genomewide analysis of DNA copy-number changes using cDNA microarrays. Nat Genet 23:41-46.

Pulido HA, Fakruddin MJ, Chatterjee A, Esplin ED, Beleno N, Martinez G, Posso H, Evans GA, Murty VV. 2000. Identification of a 6-cM minimal deletion at 11q23.1-23.2 and exclusion of PPP2R1B gene as a deletion target in cervical cancer. Cancer Res 60:6677-6682.

Rader JS, Kamarasova T, Huettner PC, Li L, Li Y, Gerhard DS. 1996. Allelotyping of all chromosomal arms in invasive cervical cancer. Oncogene 13:2737-2741.

Rao PH, Arias-Pulido H, Lu XY, Harris CP, Vargas H, Zhang FF, Narayan G, Schneider A, Terry MB, Murty VV. 2004. Chromosomal amplifications, $3 \mathrm{q}$ gain and deletions of 2q33-q37 are the frequent genetic changes in cervical carcinoma. BMC Cancer 4:5.

Redon R, Hussenet T, Bour G, Caulee K, Jost B, Muller D, Abecassis J, du Manoir S. 2002. Amplicon mapping and transcriptional analysis pinpoint cyclin $\mathrm{L}$ as a candidate oncogene in head and neck cancer. Cancer Res 62:6211-6217.

Santin AD, Zhan F, Bignotti E, Siegel ER, Cane S, Bellone S, Palmieri M, Anfossi S, Thomas M, Burnett A, Kay HH, Roman JJ, O'Brien TJ, Tian E, Cannon MJ, Shaughnessy J, Jr., Pecorelli S. 2005. Gene expression profiles of primary HPV16- and HPV18infected early stage cervical cancers and normal cervical epithelium: Identification of novel candidate molecular markers for cervical cancer diagnosis and therapy. Virology 331:269-2691.

Singh AP, Moniaux N, Chauhan SC, Meza JL, Batra SK. 2004. Inhibition of MUC4 expression suppresses pancreatic tumor cell growth and metastasis. Cancer Res 64:622-630.

Sozzi G, Huebner K, Croce CM. 1998. FHIT in human cancer. Adv Cancer Res 74:141-166.

Sugita M, Tanaka N, Davidson S, Sekiya S, Varella-Garcia M, West J, Drabkin HA, Gemmill RM. 2000. Molecular definition of a small amplification domain within $3 \mathrm{q} 26$ in tumors of cervix, ovary, and lung. Cancer Genet Cytogenet 117:9-18.

Wagner KW, Sapinoso LM, El-Rifai W, Frierson HF, Butz N, Mestan J, Hofmann F, Deveraux QL, Hampton GM. 2004. Overexpression, genomic amplification and therapeutic potential of inhibiting the UbcH10 ubiquitin conjugase in human carcinomas of diverse anatomic origin. Oncogene 23:6621-6629.

Zhang A, Maner S, Betz R, Angstrom T, Stendahl U, Bergman F, Zetterberg A, Wallin KL. 2002. Genetic alterations in cervical carcinomas: Frequent low-level amplifications of oncogenes are associated with human papillomavirus infection. Int J Cancer 101:427-433 